\title{
BUSINESS DEVELOPMENT CONSTRAINTS IN ROMANIA'S CENTER REGION ENTREPRENEURS' OPINIONS
}

\author{
Călina Ana BUŢIU ${ }^{1}$
}

\begin{abstract}
Taking into account the economic importance of business development in the region, a survey was undertaken to identify Center Region's business owners' perceptions of what constitutes barriers to growing their enterprise. To that purpose there were conducted both an analysis of the latest studies and reports on the issue and a qualitative survey of a selected lot of entrepreneurs from all six counties of the Center Region. The results support a series of conclusions with useful suggestions for the improvement of the entrepreneurial environment.
\end{abstract}

Keywords: entrepreneur, enterprise, business, constraints, Center Region

JEL Codes: A14, D78, L26, M21

\section{Introductory Remarks}

The friendliness of a business environment rests on many factors, so the analysis of the impediments, hindrances or otherwise constraints that degrade the quality of this environment can be done from several perspectives (see Kouriloff, 2000, Molina-Azorín, López-Gamero, J PereiraMoliner, and Pertusa-Ortega, 2011). Studies show that the dynamic economies are the result of many factors which include the availability of financing, of human capital, the population dynamics and unemployment, to name a few. The size of a firm, the domain of activity and even entrepreneur's age are additional variables that can influence the level of development of a firm (Marina 2016).

Looking at the role of human capital in regional development, Lee, Florida, and Acs (2004) conclude that both the availability of human capital and the existence of social diversity contribute in a positive way to the increase in the number of firms. More recently Baumgartner, Pütz, and Seidl (2013) identify three fundamental drivers of entrepreneurship - innovation, social capital and institutional change - in a European non-core regional study.

Another important factor named on top of the list by Sobel, Clark, and Lee (2007) is public policy, which is more or less the result of political decisions based upon diverse values, political affiliation, rules and regulations, and public opinion (Lybeck and Stai, 2011).

\section{Constraints encountered in Romania's Center Region. A synthesis of latest research}

Romania's Center Region consists of six counties making up a plateau inside the arc of the Carpathian Mountains, in the central area of the country. Being in the centre it has the advantage on one hand of having connexions to six of the seven other development regions of the country (ADR Centru, 2014), but the disadvantage on the other, of having no direct links to other countries. With a population of 2.63 million inhabitants as of 2017, since 2005 it constantly ranks 5th on the list of eight development regions (INS, 2017).

1 “1 Decembrie 1918” University of Alba Iulia, bcalina@yahoo.co.uk 
In the region's firms' business constraints and barriers to development analysis one used as a starting point a recent study undertaken by a team of researchers under the patronage of Small and Medium-Size Enterprise National Confederation (see Nicolescu coord., 2016).

In it $18.45 \%$ of the respondents considered that per ensemble, the business environment is favourable to entrepreneurship, placing the region in a middle position among the other regions on the list (three regions (South-East, South and Vest) scored better). As for future prospects, Center Region displays most optimism of all regions, with $23.3 \%$ of the respondents expecting an improvement of the business climate, as opposed to the South-West region for instance, where only $9.01 \%$ expect that. In terms of size, SMBs (small and medium-size businesses) display most pessimistic views, both as to present and future prospects, limited companies (SRLs) being most pessimistic about year 2017 of all other corporate structures.

At national level, the obstacles business managers complain about are as follows, in the order of frequency: bureaucracy $-61.41 \%$, fiscal regime $-54.74 \%$, corruption $-45.16 \%$, excessive controls - 44.98\%, unfair competition $40.33 \%$, drop in internal demand - $36.31 \%$, workforce availability, training and retention - $26.37 \%$, salary increases - $25.54 \%$, inflation - $21.90 \%$, competition from imports - $19.71 \%$, ageing receivables from private companies $-19.62 \%$, poor infrastructure $-18.16 \%$, cost of credit $-15.24 \%$, national currency volatility $-13.14 \%$, difficult access to credit $-12.50 \%$, ageing receivables from state agencies $-11.41 \%$, drop in export demand $10.04 \%$, access to consultancy and training services $-8.58 \%$, knowledge and adoption of EU acquis communautaire $-4.65 \%$.

On these issues Center Region is ranked below as opposed to other regions (Table 1):

Table 1.

Ranking of Center Region according to the frequency of constraints encountered by business managers

\begin{tabular}{|l|c|c|}
\hline \multicolumn{1}{|c|}{ Constraint } & $\begin{array}{c}\text { The frequency of } \\
\text { answers in Center } \\
\text { Region }\end{array}$ & $\begin{array}{c}\text { Ranking of } \\
\text { Center Region } \\
\text { among other } \\
\text { regions* }\end{array}$ \\
\hline Excessive bureaucracy & $69.90 \%$ & 1 \\
\hline Competition from imports & $27.18 \%$ & 1 \\
\hline Difficulties in receiving payments due by the state & $20.39 \%$ & 1 \\
\hline Relative volatility of national currency & $18.45 \%$ & 1 \\
\hline Access to consultancy and training services & $16.50 \%$ & 1 \\
\hline Cost of credit & $23.39 \%$ & 2 \\
\hline Difficult access to credit & $19.42 \%$ & 2 \\
\hline Knowledge and adoption of EU acquis communautaire & $9.71 \%$ & 2 \\
\hline Excessive controls & $45.63 \%$ & 3 \\
\hline Inflation & $23.30 \%$ & 3 \\
\hline Ageing receivables from private companies & $25.24 \%$ & 3 \\
\hline Drop in export demand & $14.56 \%$ & 4 \\
\hline Fiscal regime & $54.37 \%$ & 4 \\
\hline Corruption & $45.63 \%$ & 5 \\
\hline Workforce availability, training and retention & $28.16 \%$ & 5 \\
\hline Salary increases & $24.27 \%$ & 6 \\
\hline Poor infrastructure & $16.50 \%$ & 7 \\
\hline Unfair competition & $35.92 \%$ & 7 \\
\hline Drop in internal demand & $33.01 \%$ & \\
\hline
\end{tabular}

* 1 - highest frequency, 8 - lowest frequency 
Source: Nicolescu, 2017, pp. 51-52. The calculations belong to the author.

In a nutshell data shows that the entrepreneurs in the Center Region are wrestling mostly with excessive bureaucracy, competition from imports, difficulties receiving payments owed by the state, the relative volatility of national currency and a lack of consultancy and training services. The region's entrepreneurs seem less concerned than other regions' with unfair competition and internal demand.

The issue of research and innovation has also been examined in the September 2016 RDA's (Regional Development Agency's) 2014-2020 ROP's (Regional Operational Program's) study called "The Examination of Demand for Research, Development, Innovation and Technological Transfer Services by Center Regions' SMBs". The stated purpose of the study was the actualisation of RISS3 (Regional Intelligent Specialisation Strategy) and the drafting of axis 1 RDA's ROP's framework document - Concept Note.(ADR Centru, nd).

Here is a brief review of its more relevant findings: (1) out of the 205 firms that answered, $144(70.24 \%)$ stated that they launched new products on the market during the last 5 years, the majority of them (69.44\%) relying on internal financing; (2) the evaluation of technological progress in their field is overwhelmingly done by technology suppliers and rarely by universities or research centres; (3) for technology transfer services most businesses (64.39\%) choose profile events, followed by consulting and new technology acquisition assistance services; (4) out of $72.68 \%$ of firms using consulting services in the last 5 years, most $(50.34 \%)$ used it for business planning and marketing strategy and only $6(4.03 \%)$ for technology transfer.

As to the main obstacles in accessing technology transfer services, most firms mention costs firstly (68.29\%), access to technology transfer financing secondly (50.24\%) and access to business idea development financing thirdly $(42.44 \%)$.

All of the above findings, although recent, refer exclusively to the middle sector of the business world, that is small and medium size businesses. One of the aims of our research was to expand the scope of the survey on both ends of the lot - that is to capture both the rich landscape of the micro-enterprises - which in our study make up almost $40 \%$ of the number of firms - and the concerns of a few large enterprises activating in the region, so as to identify the constraints applicable to the whole business environment of the Center Region.

\section{Research Methodology}

In order to capture particular, profound and actual aspects related to the Center Region we started from the general premises that:

1. The entrepreneur is the central pillar of healthy economic growth and therefore all constraints imposed upon him inhibit the whole economic development, and that

2. While the issue of business barriers is not new by any means, their specific makeup is determined contextually.

Our survey ${ }^{2}$ focused on those realities that are regionally specific and that can elicit an economic development strategy fruitful for Center Region. Also taking into account the applicability of the results for the beneficiary of the study, we concentrated on those dimensions that can be influenced by it. The approach was mostly qualitative, that is subjective, opinion-based and overall descriptive with little explicative ambitions. Opinion surveys nevertheless have the quality of being authentic informative sources in policy development for being an honest "voice" that should be listened to by policy makers.

\footnotetext{
${ }^{2}$ The survey was part of the Regional Development Agency-financed research project called "Center Region development potential and economic prospects study", done by MANCOM CENTRU S.R.L. in 2017-2018.
} 
The survey was administered during November 2017 to a lot of 86 firms from all six counties of Center Region. A selection following an absolute proportionality model would require keeping the proportions of the population of reference, which in our case would imply a strong bias towards micro-enterprises who make up $90 \%$ of the population and out of which $40 \%$ activate in the service sector. Such a sample would have less relevance for the rest of the enterprises and due to the fact that the behaviour of the small service providers is relatively similar from managerial, financial and human resources points of view.

The final structure of the surveyed lot took nevertheless into account the Romanian business profile where micro-enterprises do predominate and is depicted in Table 2. Counties' contributions are as follows: Alba County - 20.9\% of firms, Brasov County - 17.4\%, Covasna County - 12.8\%, Harghita County - 7\%, Mures County - $19.8 \%$ and Sibiu County $-22.1 \%$ of all firms.

Table 2.

\section{Lot structure}

\begin{tabular}{|l|c|c|c|c|c|}
\hline & \multicolumn{4}{|c|}{ Size } & \multirow{2}{*}{ Total } \\
\cline { 2 - 5 } & $\begin{array}{c}\text { Micro } \\
\text { Enterprise }\end{array}$ & $\begin{array}{c}\text { Small } \\
\text { enterprise }\end{array}$ & $\begin{array}{c}\text { Medium-size } \\
\text { Enterprise }\end{array}$ & $\begin{array}{c}\text { Large } \\
\text { Enterprise }\end{array}$ & $\mathbf{8 6}$ \\
\hline Number of firms & 34 & 27 & 15 & 10 & $\mathbf{8 6}$ \\
\hline Proportion (\%) & $39.5 \%$ & $31.4 \%$ & $17.4 \%$ & $11.6 \%$ & $\mathbf{1 0 0 \%}$ \\
\hline
\end{tabular}

The data collection instrument was a questionnaire designed mostly around opinions, but also with some factual questions. The majority of the questions had pre-cast answers, but some leaving room for open responses that could complete the palette of problems perceived by respondents.

\section{Results and discussions}

\section{Firm's Location}

When asked to rate the location of the firm on a scale from 1 to 10 respondents appreciated their location positively overall with an average of 7.7. Most respondents (20) chose level 8, 19 of them chose level 10 and 18 level 7 out of a total of 86 .

The degree of satisfaction with the location clearly follows the size of the firm. Microenterprises are most dissatisfied with their location, whereas large firms display the highest frequency of satisfaction rating their location as 6 and above (Table 3).

In relation to rural/urban space most firms are satisfied with the location; 15 out of a total of 18 firms in rural areas rate their location as 7 and above - 5 of which appreciate it as extremely favourable (10) - and only 3 as below average. Some explanations can be found in the open-ended answers and pertain mostly to the availability of agricultural land, the proximity of urban areas or to firm's particular tradition. In the urban areas the ratings are even more concentrated towards the upper levels of the satisfaction scale, the reasons having to do with the centrality of the location, the accessibility of the road and communication infrastructure and the preservation of their traditional locations.

Table 3.

Satisfaction with location in relation to firm's size

\begin{tabular}{|c|c|c|c|c|c|}
\hline \multirow{2}{*}{$\begin{array}{c}\text { How do you appreciate } \\
\text { your firm's location on a } \\
\text { scale from 1 to 10? }\end{array}$} & $\begin{array}{c}\text { Micro } \\
\text { Enterprise }\end{array}$ & $\begin{array}{c}\text { Small } \\
\text { Enterprise }\end{array}$ & $\begin{array}{c}\text { Medium-size } \\
\text { Enterprise }\end{array}$ & $\begin{array}{c}\text { Large } \\
\text { Enterprise }\end{array}$ & Total \\
\hline 1 extremely unfavourable & 0 & 0 & 0 & 0 & 0 \\
\hline
\end{tabular}




\begin{tabular}{|l|c|c|c|c|c|}
\hline 2 & 1 & 0 & 0 & 0 & 1 \\
\hline 3 & 0 & 1 & 0 & 0 & 1 \\
\hline 4 & 2 & 0 & 1 & 0 & 3 \\
\hline 5 & 6 & 1 & 1 & 0 & 8 \\
\hline 6 & 0 & 2 & 2 & 1 & 5 \\
\hline 7 & 5 & 5 & 5 & 3 & 18 \\
\hline 8 & 12 & 7 & 0 & 1 & 20 \\
\hline 9 & 4 & 5 & 1 & 1 & 11 \\
\hline 10 extremely favourable & 4 & 6 & 5 & 4 & 19 \\
\hline Total & 34 & 27 & 15 & 10 & 86 \\
\hline
\end{tabular}

As to the reasons behind a particular choice of location, the residence of the owner tops the list, followed by the availability of utilities and the proximity to the markets. The area's economic power and the workforce qualifications/costs are not among the top three reasons, but follow next. Business-friendly administration and industrial parks are rated even lower, the proximity of friends being of last concern (Graphic1).

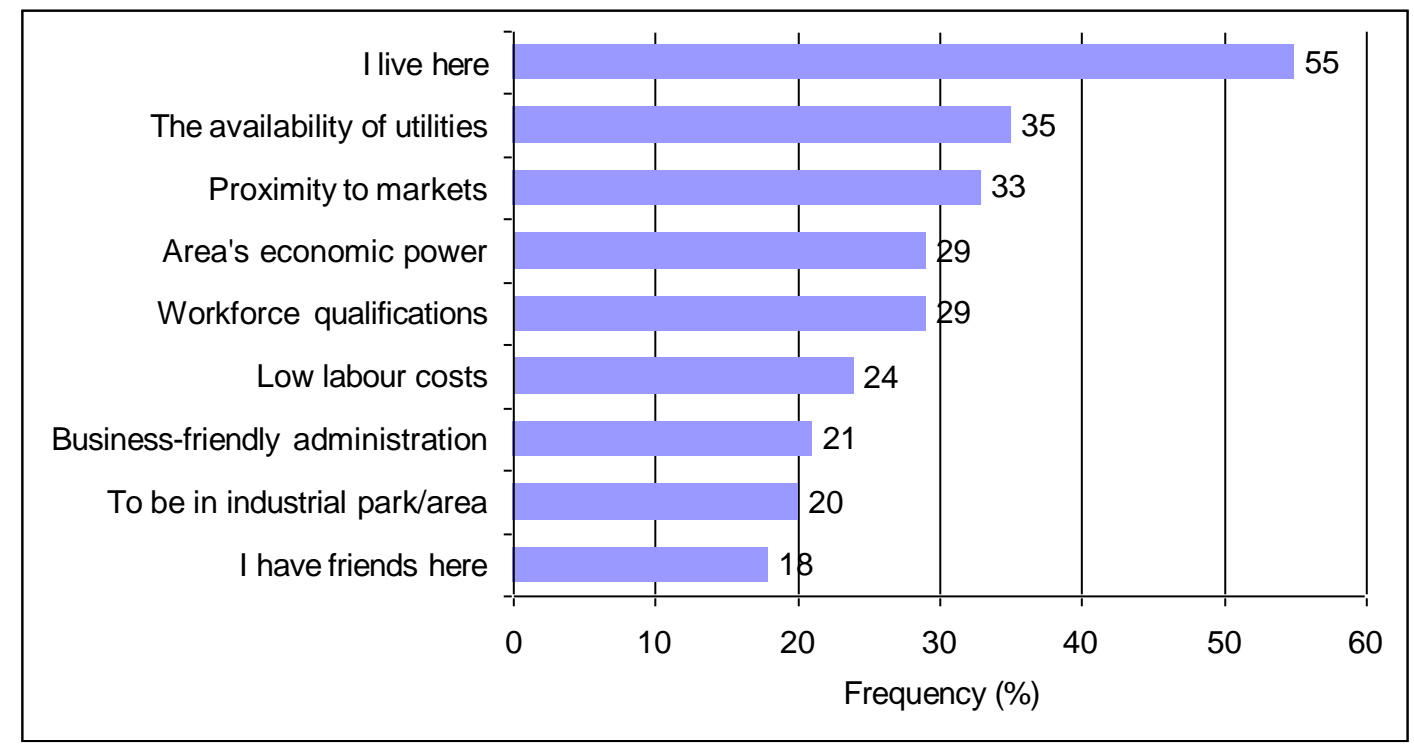

Graphic 1. Reasons for choosing a location

Drilling down to the specific local conditions we then asked business owners to rate on a scale from 1 to 10 several factors with impact on their success, firstly on their importance and secondly on respondents' satisfaction with their status quo. The results from averaging the scores are displayed in Graphic 3.

With an average of 9.03, the highest degree of importance is given to the availability of specialised workforce, although the degree of satisfaction with it is one of the lowest (5) resulting in a gap of 4.03 points. What is even more remarkable is that the 9 most important conditions have also the widest gaps between their importance and the level of satisfaction with them. The next 5 conditions ranked by their gaps are: (1) consultancy and assistance from public institutions (a gap of 3.36 points), (2) local taxation environment $(3,32)$, (3) level of qualification for applying workforce (3.19), (4) transparency of LPA (Local Public Administration) (3.15), receptivity of LPA to firm's problems (3.02).

There are however two conditions for which the level of satisfaction is actually greater than the level of their importance, that is (1) the proximity of universities or research centres (5.6 
satisfaction over a 4.8 importance) and (2) the connectivity to rail transport network (3.67 satisfaction over a 3.41 importance).

A second noticeable issue is that while the importance of workforce qualification ranks first on the list, the proximity of universities or research centres ranks second last. One ironical interpretation could be that business managers undervalue the role of universities in preparing their so much needed workforce. A second, more plausible conclusion is that most firms need mid-level professionally qualified workers (tradesmen) which universities don't supply. This conclusion is confirmed in the next section of the study.

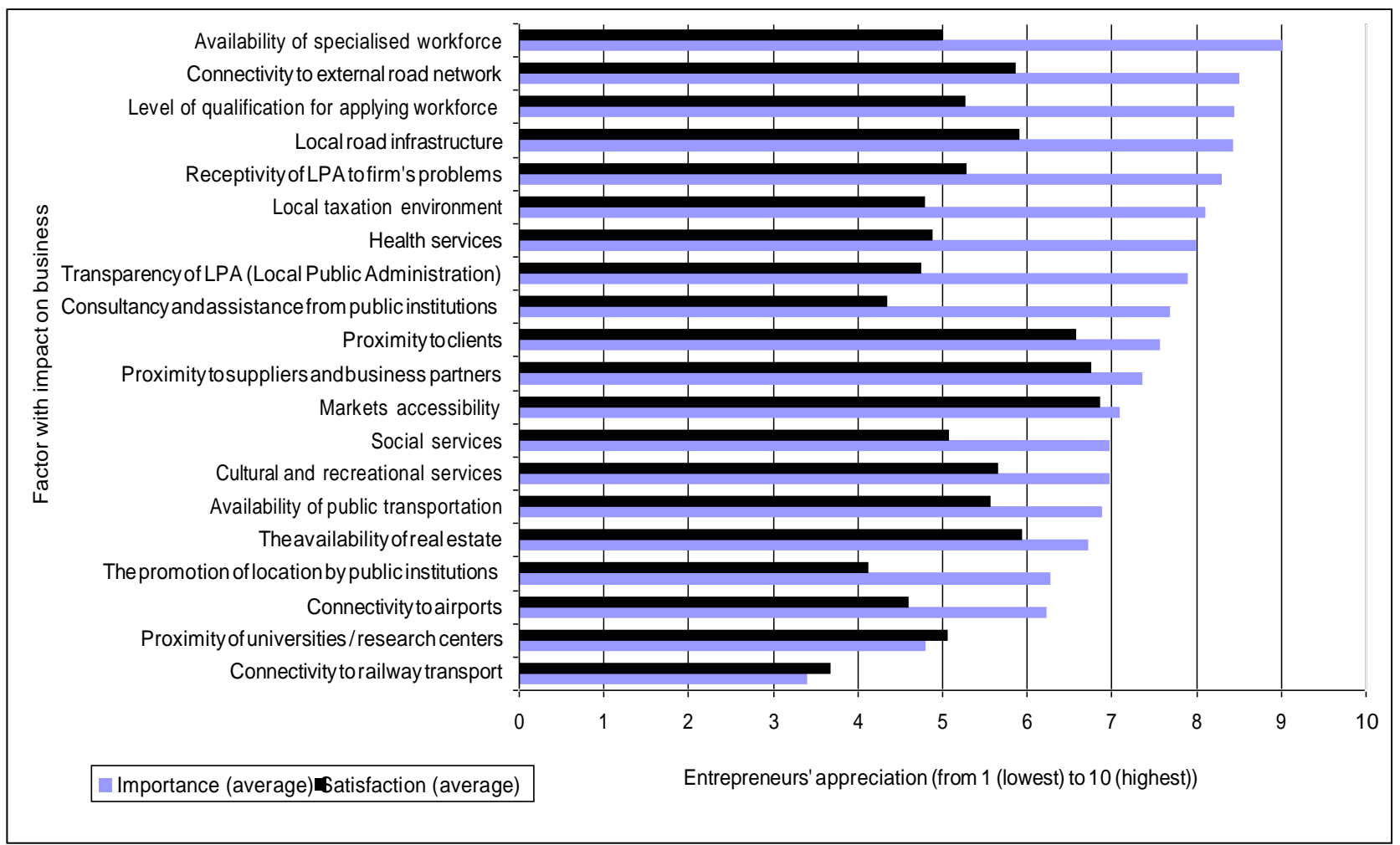

Graphic 2. Importance and satisfaction with local conditions affecting the business (averages)

\section{Workforce}

When asked about the most sought-after level of qualification for their workers, the majority of entrepreneurs demanded primarily professional workers (tradesmen) followed by mid-level workers. Both upper-level university graduates and workers without any qualifications at all were rated in less demand. Demand for upper-level graduates were mostly in IT ( 5 answers), followed by medicine, education, quality control, management and engineering, all with single answers.

Most answers confirmed the need for tradesmen of all kind, specifically: mechanic (auto mechanic, electro-mechanic, agricultural mechanic) - 21 answers, construction workers - 17, electrician - 16 , welder - 12 , machinist - 10, driver - 8, textile/metal worker - 7, carpenter - 6 , pipe fitter - 6, baker - 4, agricultural worker/beekeeper - 2, and 1 answer each for: cook, sales agent, road worker, carpenter, industrial electro-mechanic, concrete worker, barber, hairdresser, manicurist, pedicurist, isolator, locksmith, waiter, food salesperson, dairy preparer, sculptor, welder, upholster, blanket maker, mattress maker, auto body worker, bricklayer, stone layer, animal worker, house painter, cast maker, carpet layer, painter.

\section{Business financing}

As depicted in Graphic 3 firms were financed mostly from own resources, $81.4 \%$ at the start and $61.6 \%$ through ongoing operations. Bank credit is next used by $9.3 \%$ of the firms at the start 
and $27.9 \%$ during operations. Family and friends resources although small overall, gain a bit of importance during the operational stage and so do funds from public sources. The numbers suggest a certain degree of risk aversion, possibly due to the unpredictability of the business climate in the region.

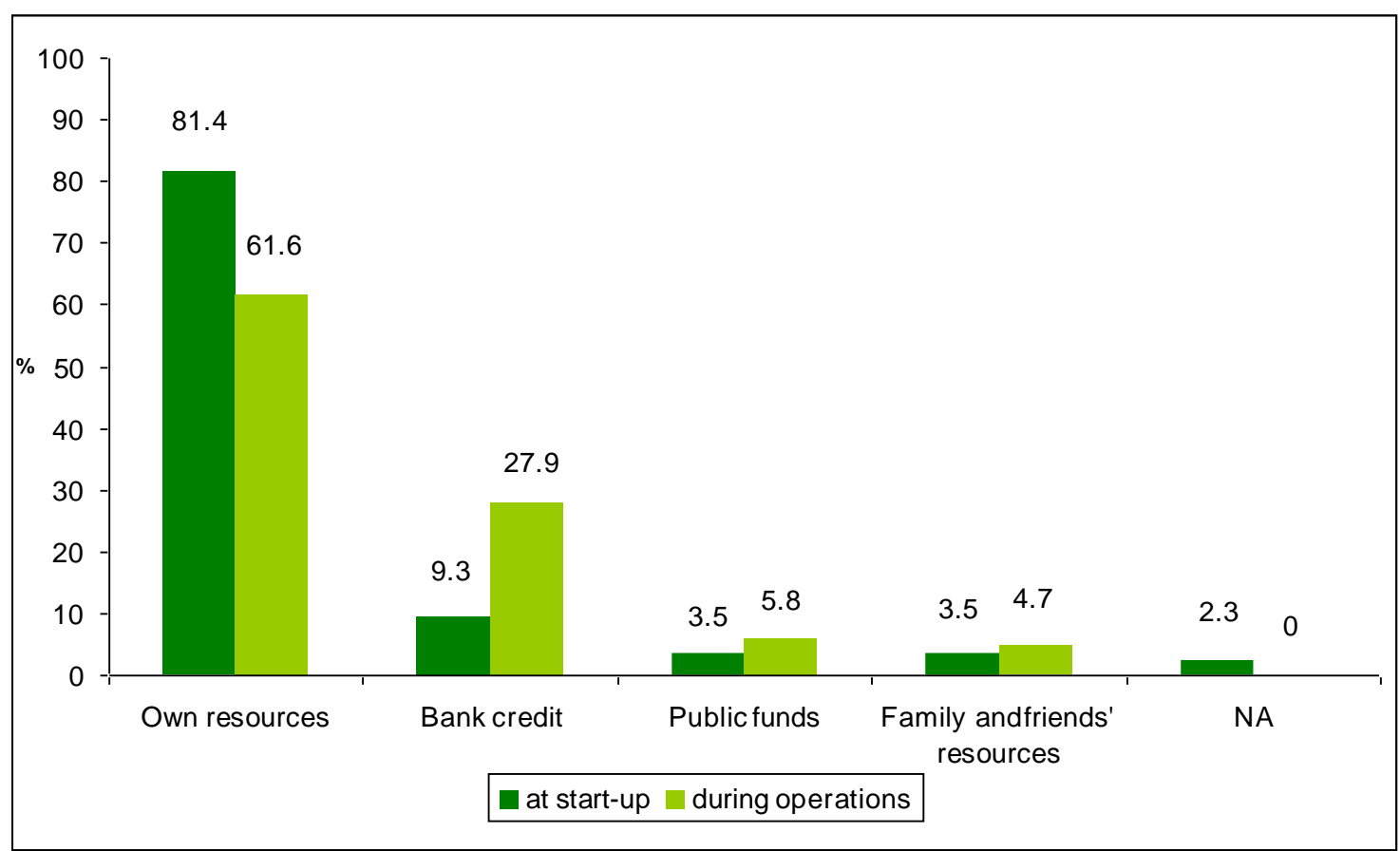

Graphic 3. Main sources of financing

Although public financing ranks low in actual use, more than half of the entrepreneurs $(52.3 \%)$ consider it as being very important, especially those owning small businesses. Private financing is important for $37.2 \%$ of respondents (Graphic 4).

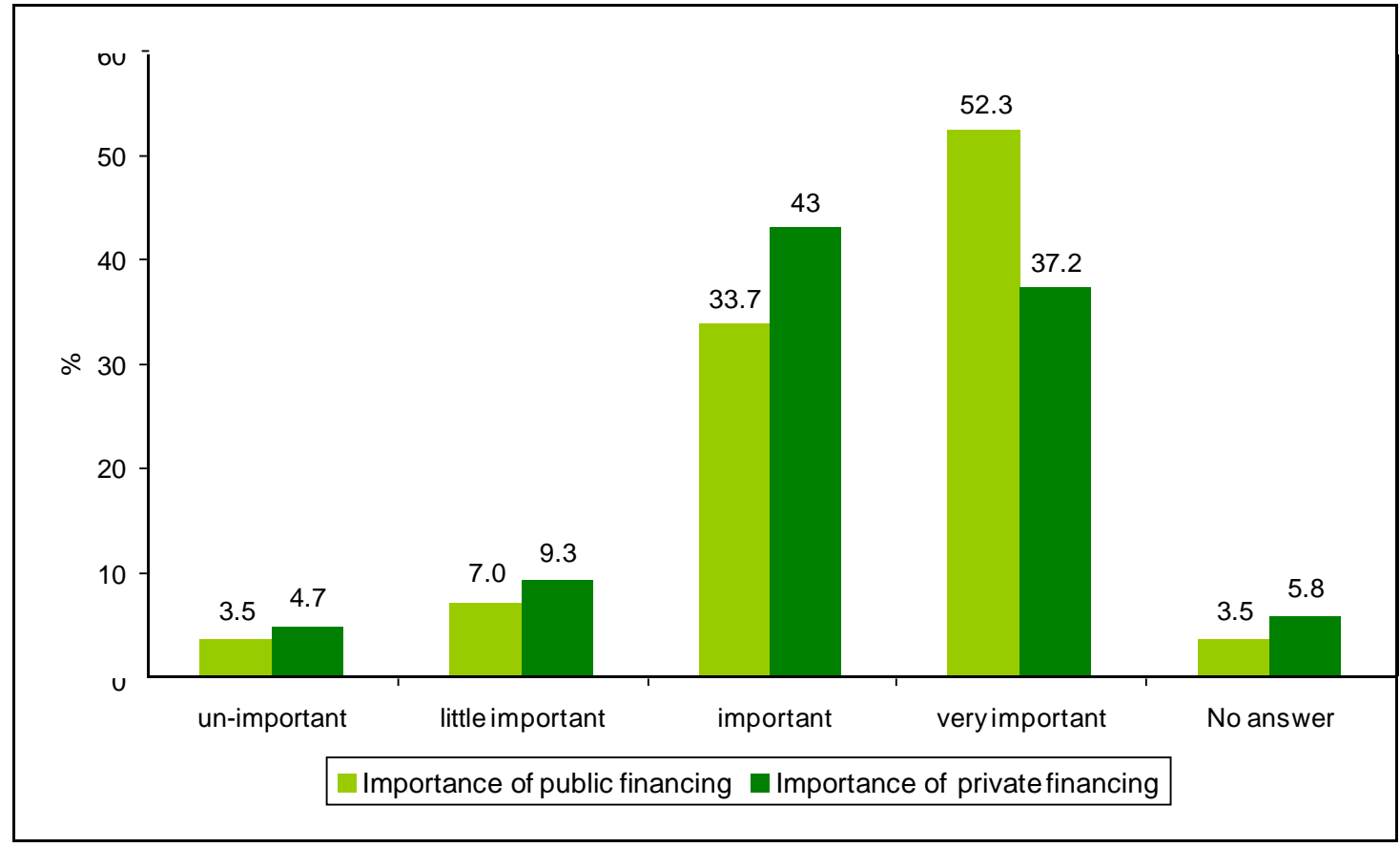

Graphic 4. The importance of public $\mathbf{v}$ private financing 
When questioned on constraints to public financing $55.8 \%$ of respondents qualified bureaucratic procedures as affecting their business "very much". Also delays in contracting and cofinancing requirements were high on the list. Less important seems to be the manner of presenting the information.

It is also noticeable a relatively high non-response rate to tight deadlines and delays in contracting (Table 4).

Table 4.

The importance of some constraints to public financing (\%)

\begin{tabular}{|l|r|r|r|r|r|}
\hline $\begin{array}{c}\text { For public financing } \\
\text { matters... }\end{array}$ & $\begin{array}{c}\text { The manner of } \\
\text { presenting the } \\
\text { information }\end{array}$ & $\begin{array}{c}\text { Bureaucratic } \\
\text { procedures }\end{array}$ & $\begin{array}{c}\text { Co-financing } \\
\text { requirements }\end{array}$ & $\begin{array}{c}\text { Tight } \\
\text { deadlines }\end{array}$ & $\begin{array}{c}\text { Delays in } \\
\text { contracting }\end{array}$ \\
\hline at all & 14 & 8.1 & 8.1 & 8.1 & 8.1 \\
\hline little & 20.9 & 4.7 & 27.9 & 25.6 & 15.1 \\
\hline much & 40.7 & 27.9 & 24.4 & 24.4 & 29.1 \\
\hline very much & 16.3 & 55.8 & 33.7 & 30.2 & 37.2 \\
\hline no answer & 8.1 & 3.5 & 5.8 & 11.6 & 10.5 \\
\hline
\end{tabular}

Respondents were also asked to name other constraints imposed by public funding that had not been mentioned. The answers worth mentioning: procedural inconsistencies, burdensome specifications/requirements, conditional purchasing of additional products or services, the level of detail for special purchases, lack of alignment between monitoring indicators and chapters in the guides.

When questioned on constraints to private financing, the rate of non-response was much lower, the answers being grouped as follows: no obstacles - 14 answers, large collateral and interest charges - 10, bureaucratic procedures - 8, documentation requirements - 5, economic instability - 3, the lack of own resources - 1, no interest in private financing - 6 answers.

\section{Business assistance and consulting}

Other issues of interest for our study were those of business assistance from public institutions and consultancy services from private providers. We learned that only 20 firms $(23.3 \%$ of the lot) benefited from public assistance and 47 (57.4\%) from private consulting.

Of those 20 only 13 firms were satisfied and very satisfied with public assistance services (10 and 3 respectively), the rest being either dissatisfied (5) or very dissatisfied (1); there was also one non-response. Since more than half of the firms that benefited from public assistance declared themselves satisfied and very satisfied, one could reason that the problem could be the accessibility of the services and not necessarily their quality. In fact when those that didn't benefit were asked about the reasons, most of them answered that they didn't need it. Others justified it with a lack of trust in public service or with a lack of knowledge of such services.

The number of satisfied beneficiaries with private consulting is more than double of those benefiting from public assistance, the overall level of satisfaction being higher. 34 respondents declared themselves satisfied and very satisfied (21 and 13 respectively), 6 dissatisfied, 1 very dissatisfied and 6 didn't answer. Thus $82.9 \%$ of the 47 firms declared themselves satisfied and very satisfied with private consulting.

\section{Digitalisation}

While digital technology is on the forefront of development everywhere, EUROSTAT data shows that at $42 \%$ of firms having a website, Romania ranks last in European Union, where the average rate is $77 \%$. Employee use of computers is also low at $33 \%$, second lowest before Bulgaria 
at $30 \%$. Other data from European statistics confirm an overall low use of digital technologies by Romanian firms. ${ }^{3}$

Our subject firms from Center Region confirmed to a certain degree the low overall level of digitalisation of Romanian firms, even though the expectation was that technology's role in a firm's development, regardless of its domain of activity, will be recognized at least declaratively. Digitalisation implies not just computer use, but all sorts of services that the firms can benefit from through the use of information and communication technologies (IT\&C) like broadband connections, electronic commerce, electronic billing, cloud services and others.

As shown in Table 5 only $64 \%$ of the firms acknowledge digitalisation as being very important and $27.9 \%$ as important. A single micro-firm found digitalisation as unimportant and 3 as little important.

Table 5.

The importance of digitalisation in firm's activity

\begin{tabular}{|l|r|}
\hline Degree of importance & \multicolumn{1}{|c|}{$\%$} \\
\hline unimportant & 1.2 \\
\hline little important & 3.5 \\
\hline important & 27.9 \\
\hline very important & 64.0 \\
\hline non response & 3.4 \\
\hline Total & $\mathbf{1 0 0}$ \\
\hline
\end{tabular}

The importance of digitalisation tends to increase in recognition with the size of the company, 9 out of the 10 large companies recognizing it as very important and 1 as important. Micro-enterprises' responses were more spread over the whole spectrum of answers.

\section{Constraints on firms in the home county}

In the hope of having entrepreneurs transcend their own particular interests they were also asked their opinions on issues hindering not just their own firm, but also firms in general in their home county.

The respondents had the choice of answering "Yes", "No" and "I cannot appreciate". The most frequent concerns materialised through categorical "Yes"-es turned out to be the shortage of workforce ( $83.8 \%$ of answers), followed by personnel fluctuations (82.7\%), and burdensome bureaucratic procedures $(79.3 \%)$. The least three concerns were the lack of utilities (33\%), poor transport infrastructure $(51.9 \%)$ and poor firms' co-financing abilities $(52.6 \%)$. The three most frequent "I cannot appreciate" answers referred to lack of investment in research and development (26.9\%), poor firms' project co-financing abilities (24.7\%) and indifferent public administration $(22.4 \%)$.

\footnotetext{
${ }^{3}$ Financial institutions and firms with less than 10 employees were excluded.
} 


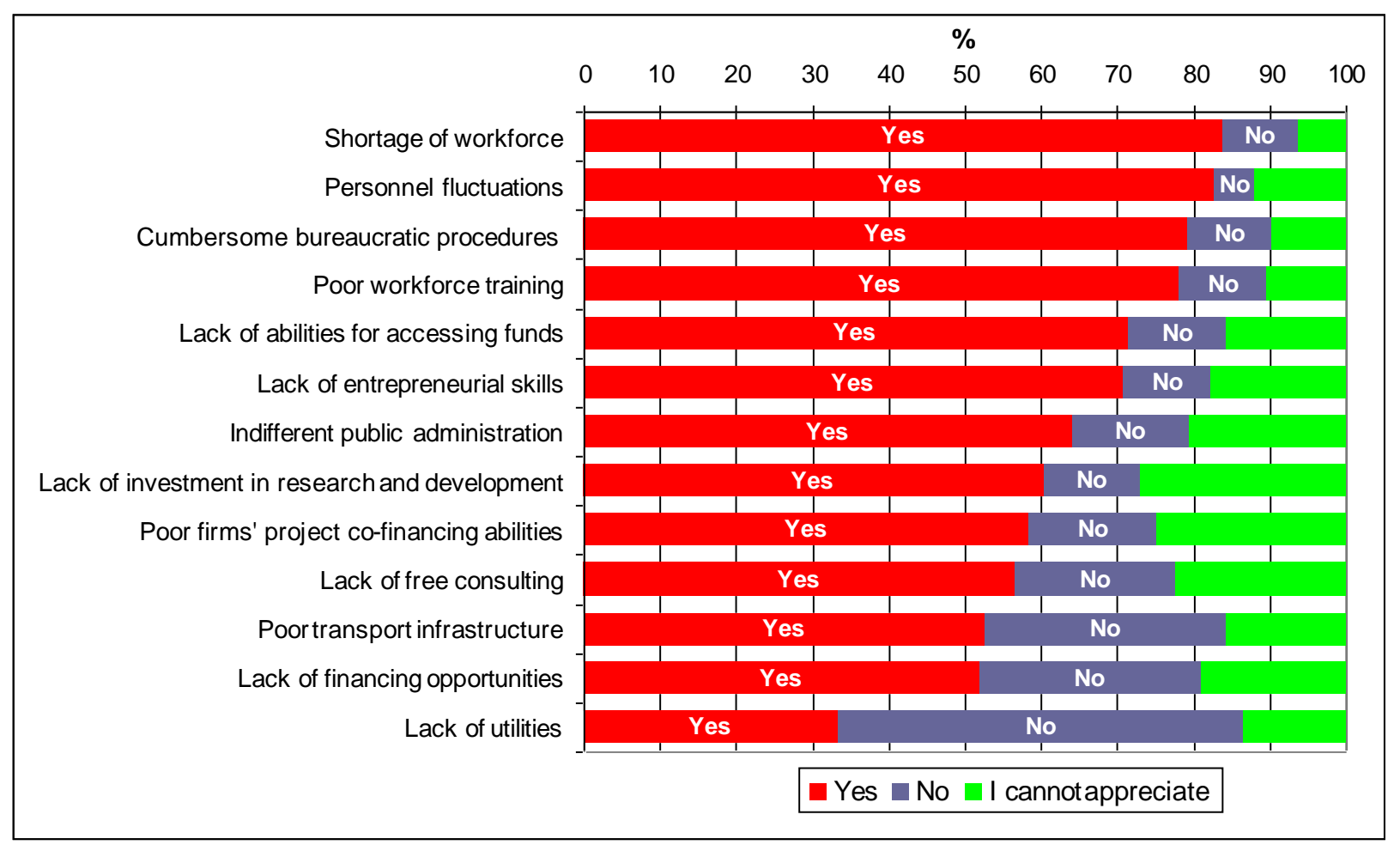

Graphic 5. Constraints on firms in the home county

Firms' recommendations for improvement in the business environment

The open ended question that was asked was "What recommendations/proposals would you address to county/local public institutions that would stimulate the creation and development of business in the region?" The answers were analysed and grouped according to the frequency of certain key concerns that emerged and are outlined in Table 6.

Table 6.

\section{Recommendations addressed to county and local public institutions}

\begin{tabular}{|l|c|}
\hline Recommendation & Frequency \\
\hline Reduction in bureaucracy (red tape) & 14 \\
\hline More receptiveness to the problems faced by/collaboration with the firms & 13 \\
\hline Better infrastructure and utilities development & 9 \\
\hline Digitalisation & 9 \\
\hline Free consulting services & 7 \\
\hline Professionalism & 7 \\
\hline Better promotion of the firms, both internally and internationally & 5 \\
\hline More accessible financing & 5 \\
\hline Better match between training and labour market & 5 \\
\hline The promotion of dual professional education (on-the-job training) & 5 \\
\hline Reduction in taxes & 4 \\
\hline More transparency & 4 \\
\hline Better response times & 4 \\
\hline Free entrepreneurial training & 3 \\
\hline The attraction of investors & 2 \\
\hline Fiscal facilities & 2 \\
\hline Business start-up incubators & 2 \\
\hline Development of industrial parks in correlation to utilities & 2 \\
\hline
\end{tabular}




\begin{tabular}{|l|c|}
\hline More tourism promotion of the county & 1 \\
\hline Exchanges of expertise with successful foreign institutions & 1 \\
\hline Viable development strategies & 1 \\
\hline Friendlier business legislation & 1 \\
\hline Technology transfer centres & 1 \\
\hline The encouragement of national and international partnerships & 1 \\
\hline One-stop office & 1 \\
\hline More flexibility & 1 \\
\hline Information campaigns for business development & 1 \\
\hline Cutting down social assistance to able unemployed persons & 1 \\
\hline An airport in Braşov city area & 1 \\
\hline
\end{tabular}

On top of the list is a reduction in bureaucracy. This demand has been spelled out in both succinct and elaborate manners, including references to business authorisations, construction permits, documentation in general, and a streamlining of procedures; in blunt language - red tape. More digitalisation (of public services) also appears in connection to this issue. Second on the list of grievances are improvements in the relationship between public entities and business firms, specifically more receptiveness from public institutions, improved mutual information, more partnerships and better collaboration, in general. In third place appear both the need for an improved infrastructure and better utilities and the issue of digitalisation in public interface in general. And finally but still frequently mentioned are the need for free consulting services (public assistance) and concerns in connection to the professionalism of public workers.

There is also a series of less frequent but numerous answers that is worth considering as an illustration of a likely wider list of challenges faced by employers in the region and which should be taken into view by public agencies. While not making up a substitute for a real dialogue between entrepreneurs and government, these suggestions may nevertheless provide useful clues in developing a more comprehensive business and social welfare strategy. To mention just a few: the promotion of tourism in the county, exchanges of expertise with successful foreign public institutions, the design of sustainable development strategies and others.

Recommendations for private entities were also surveyed through the open-ended question "What recommendations/proposals would you address to private institutions (banks, professional organisations, chambers of commerce, business clubs etc.) that would stimulate the creation and development of business in the region?" Through a similar analysis and clustering as with the public institutions we extracted the concerns outlined in Table 7.

Table 7.

\section{Recommendations addressed to private institutions}

\begin{tabular}{|l|c|}
\hline Recommendation & Frequency \\
\hline General recommendations & 7 \\
\hline Communication / Information & 3 \\
\hline Professionalism & 3 \\
\hline Receptiveness to the needs and problems of the firms & 3 \\
\hline Collaboration and partnerships & 3 \\
\hline Government lobby & 3 \\
\hline Implication (activism, visibility etc.) & 2 \\
\hline Reduction in bureaucracy & 1 \\
\hline Respect towards the client & 1 \\
\hline More tradeshows in IT & 1 \\
\hline Dual education institutions (combining theory with on-the-job training) & \\
\hline
\end{tabular}




\begin{tabular}{|l|l|}
\hline Quality consultancy & 1 \\
\hline Flexibility & 1 \\
\hline More interest in small firms & 1 \\
\hline On-the-job training for students & 1 \\
\hline Digitalisation & 3 \\
\hline Recommendations for Banks & 3 \\
\hline Smaller interest rates & 2 \\
\hline Easier access to credit & 2 \\
\hline Smaller commissions & 2 \\
\hline A better understanding of the economic environment & 1 \\
\hline Individualised offer of products and services & 1 \\
\hline More accent on quality & 1 \\
\hline The promotion of local industry & 1 \\
\hline Accepting the firm as collateral & 1 \\
\hline Recommendations for Chambers of Commerce & 1 \\
\hline Dual education & 1 \\
\hline Better collaboration efforts with foreign investors & 1 \\
\hline The simplification of commerce registry & 1 \\
\hline Streamlining of bureaucratic procedures & 1 \\
\hline Business start-up incubators & 1 \\
\hline Professional training & 2 \\
\hline Networking & 1 \\
\hline Recommendations for Professional Organisations & \\
\hline Information & \\
\hline Preparing the firms for community market & \\
\hline
\end{tabular}

Communication/information, lobby and professionalism are the top three demands on the general wish list of firms in Table 7. Grouping the list on the type of institutions addressed to reveals that most wishes were addressed to banks in connection to interest rates, commissions and credit access requirements. The apparent lack of understanding of the business environment displayed by the banks finds echo in explicit recommendations from two entrepreneurs. To quote one of them "The bank personnel should have a change of mentality and place themselves on the opposite side of the counter so to better understand that their salaries and jobs rest on each decision their clients have to make. Stay there and explain, and renegotiate rates and commissions where they should".

The Chambers of Commerce are advised to support dual education (theoretical and practical i.e. on-the-job training), more collaboration with foreign investors, less bureaucracy and more support to business incubators. More public awareness of their role would also be welcome since to quote one of the entrepreneurs interviewed, "The Chambers of Commerce and Industry should implicate themselves more because the majority of entrepreneurs don't even know what exactly are they doing...".

The Professional Organisations did not receive many recommendations, either for not being sufficiently visible to the business environment or for not having the means in the current socioeconomic context to address many of the problems encountered by respondents. The general lack of information about them suggests the first reason. 


\section{Conclusions}

The recent studies at national level conclude that the majority of entrepreneurs in Center Region have a rather positive appreciation of the current business climate and an optimistic view of future prospects overall. Small firms however are facing more and diverse challenges than the larger ones, fact which contradicts the broad economic policy objectives both national and European.

If the opportunities envisioned by the entrepreneurs of the Center Region in 2016 above the averages from other regions were the acquisition of grants, the diversification product offer and the employment of new technologies, the challenges met by them are excessive bureaucracy, competition from imports, difficulties receiving payments owed by the state, the relative volatility of national currency and difficulties in accessing assistance and consultancy services. While there were improvements in access to financing and technology, there still are ongoing risks, not as much coming from the unpredictability of the markets, but rather associated with national and local public institutions.

Our 2017 research data shows that the choice of location for firms in Center Region is generally driven by access to infrastructure, utilities and proximity of the markets, with the exception of micro-firms where an important role is played by the proximity of entrepreneur's residence.

The vast majority of firms being small, their start-up is financed mostly from own resources with small additions from friends' and family's and less so from classical credit. This may indicate a certain degree of aversion to risk by both the entrepreneurs and the classical creditors. Banks are more likely to finance lower risk, continuing operations, rather than provide seed capital. Access to public funding although very high on the list of employers is often criticised for excessive red tape, delays in contracting and co-financing requirements.

Consultancy services and assistance from public institutions is also desired by entrepreneurs. While about half did use private consulting in the past, only a fifth benefited from public assistance, either because of poor offer or because a lack of awareness of its availability. With private consulting, firms are satisfied overall, but would like to see a lowering of costs through facilities like free public consulting.

While the availability of specialised and qualified workforce is very critical to the operation of the business, the supply of competent workers is questionable for reasons having to do with the quality of training, the opportunities for gaining experience, but probably also with demographics and the migration of young workers seen in other national studies. Most employers clearly forewarn of the shortage of qualified mid-level specialised tradesmen like mechanics, electricians, pipe-fitters, welders and so on, and of the need for dual education through which professionals gain not just theoretical knowledge, but also hands-on practical training.

Entrepreneurs' appeals to public institutions are for more involvement with their concerns either through less red tape, more assistance, easier access to public funding and streamlined procedures via digitalisation. Private financial institutions are asked for lower costs, easier availability of credit and more receptiveness and individualisation of services. And finally the local chambers of commerce should do more to attract investment, support dual education, create more business incubators and reduce bureaucratic requirements in general.

\section{Acknowledgements}

This work would not have been possible without the support of Center Development Region Agency, not only by financing the project but also by periodic feed-back provided. I am greatful to those whom I have had the pleasure to work with in this project: coordinator Birgit Schliewenz and team members Andreas Kotzorek, Ionela Paven, Meda Firu and Cătălin Stanciu. 


\section{References}

1. Agenţia de Dezvoltare Regională Centru (ADR Centru), 2014. Planul de Dezvoltare a Regiunii Centru 2014 - 2020. Analiza socio-economică, http://regio-adrcentru.ro/planul-de-dezvoltare-aregiunii-centru-2014-2020/.

2. Agenţia de Dezvoltare Regională Centru (ADR Centru), nd. Examinarea cererii de servicii de cercetare, dezvoltare, inovare si transfer tehnologic in randul IMM din Regiunea Centru Analiza de chestionare aplicate in procesul de elaborare a Concept Note, http://regioadrcentru.ro/wp-content/uploads/2015/02/Analiza-nevoii-de-inovare-in-cadrul-IMM-urilor.pdf.

3. Baumgartner, D., Pütz, M., and Seidl, I., 2013. What Kind of Entrepreneurship Drives Regional Development in European Non-core Regions? A Literature Review on Empirical Entrepreneurship Research, European Planning Studies, 21:8.

4. Institutul Naţional de Statistică (INS), 2017. Balanţa forţei de muncă la 1 ianuarie 2017, http://www.insse.ro/cms/sites/default/files/field/publicatii/balanta_fortei_de_munca_la_1ianuari e_2017.pdf.

5. Kouriloff, M., 2000. Exploring Perceptions of A Priori Barriers to Entrepreneurship: A Multidisciplinary Approach, Entrepreneurship Theory and Practice, Vol. 25, Issue 2.

6. Lee S.Y., Florida, R., and Acs, Z., 2004. Creativity and Entrepreneurship: A Regional Analysis of New Firm Formation, Journal Regional Studies, Volume 38, Issue 8.

7. Lybeck, K., Stai, B., 2011. Public Policy \& Entrepreneurship, Academy of Entrepreneurship Proceedings, International Conference, Orlando, Florida, April 5-9. 2011.

8. Marina, L., 2016. Determinants Of Entrepreneurs' Perception About The barriers In Developing A Business In Alba Iulia, Annales Universitatis Apulensis Series Oeconomica, Nr. 18 / 2016, volumul 2, http://www.uab.ro/oeconomica/.

9. Molina-Azorín, J.F., López-Gamero, M.D., Pereira-Moliner, J., and Pertusa-Ortega, E.M., 2011. Mixed methods studies in entrepreneurship research: Applications and contributions, Entrepreneurship \& Regional Development, Vol. 2, Issues 5-6.

10. Nicolaescu, O. coord., 2016. Carta albă a IMM-urilor din România. Raport de cercetare, Nr. 14, Consiliul Naţional al Întreprinderilor Private Mici şi Mijlocii din România, http://www.aippimm.ro/files/articles_files/57/6521/carta-alba-a-imm-urilor-din-romania2016.pdf.

11. Sobel, R.S., Clark, J.R., Lee, D.R., 2007. Freedom, barriers to entry, entrepreneurship, and economic progress, Rev Austrian Econ,. Volume 20, Issue 4. 